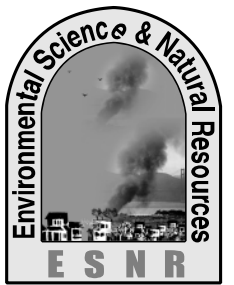

\title{
Water Quality Parameters and Sanitation Status of the Educational Institutions at Jamurki, Mirzapur, Tangail
}

\author{
M. M. Hoque, A. K. Miah, M. S. Rahman, M. S. Rahaman* and M. K. Hossain \\ Department of Environmental Science and Resource Management \\ Mawlana Bhashani Science and Technology University, Tangail \\ *Corresponding author: sadeqer08015@yahoo.com
}

\begin{abstract}
The study was conducted to investigate the water quality parameters and sanitation status in the educational institutions at Jamurki Union in Mirzapur of Tangail district. The study determined different water quality parameters such as As, $\mathrm{pH}, \mathrm{Fe}$, DO, TDS and EC. Most of the investigated water quality parameters in the study area were suitable for drinking purposes comparing with standard values. The range of investigated parameters in the study area of educational institutions were As 0 to $15 \mathrm{ppb}$, pH 6.5 to 8.5 , Fe 0.1 to $0.9 \mathrm{ppm}$, DO 2.5 to $4.0 \mathrm{mg}$, TDS 121 to $445 \mathrm{ppm}$, EC 246 to $592 \mu \mathrm{s} / \mathrm{cm}$ and most of the color of water samples water were standard means colorless and the odor of samples were also good However, the values of $\mathrm{pH}$ was exceeded somewhere. All of the tube wells were free from Arsenic. Most of the samples exceeded the standard values of Fe. The study identified the various problems of sanitation systems in the educational institutions e.g. Poor sanitation condition, dirty toilets, and insufficient toilets for female students.
\end{abstract}

Key words: Jamurki union, Pollution, School, Water pollution

\section{Introduction}

Water is one of the most important components of the physical environment. Ground water accounts for nearly $100 \%$ of drinking water supply. Due to lack of safe drinking water various diseases occur. The quality of water is of vital concern for mankind since it is directly linked with human welfare (De, 2005). Sanitation means the practice of effecting healthful and hygienic conditions. It also involves the study and use of hygienic measure. A proper qualified water supply greatly influences the sanitation system of a certain area. If we consider an educational institution than here it should be ensured first a proper qualified water supply system \& sanitary latrine to develop sanitation system. Water supply and safe disposal of human wastes are most important for the protection of health. The high rate of incidence of diarrheal diseases and infant mortality in developing countries are attributed to lack of water supply and sanitation (Ahmed and Hossain, 2008). It is now well established that health education or hygiene promotion must accompany sufficient quantities of safe water and sanitary disposal of excreta to insure the control of water and sanitation related diseases (Ahmed and Hossain, 2008).

So beside environmental sanitation practice a good water supply system is also very important to ensure a healthy community. In educational institution these practices will play a vital role so that the students of institution can teach the water supply and sanitation practices to their family members. In this way a large number of people of the country may be aware about sanitation and water supply system. But the quality of water is decreasing day by day due to various anthropogenic and natural activities all over the country. Especially in Mirzapur upazila of Tangail district the degradation of water quality is more significant. So investigation of water quality and sanitation practices at Mirzapur upazila of Tangail districts is very urgent to provide valid instruction to the concerned students.

\section{Materials and Methods}

The study was carried out through analytical method and social surveys. The analytical study was carried out to determine the physical and chemical properties of water and to find out the suitability of this water for using as drinking and sanitation purposes for the students by comparing the values with the standard levels of water quality parameters. The survey was carried out to determine the sanitation status, source of water and the ratio of using hygienic sanitation systems among the teachers and students of the educational institutions.

\section{Location of the study area}

The study was conducted at Jamurki union in Mirzapur of Tangail district of Bangladesh.

\section{Data and sample collection}

Data were collected from the teachers and students by questionnaire survey and laboratory analysis of samples. The water samples were collected from 1 . Jamurki Kacharibari Hafizia Madrasha, 2. Jamurki Govt. Primary School, 3. Stiachara Shibnath Girls High School, 4. Jamurki N.S.A.G. High School, 5. Satiachara Govt. Primary School, 6. Khaza Kutub Uddin K. G. School, 7. PakullaGovt. Primary School, 8. Mdrasha-E-Thafijul Kuran,Chokoria, 9. Baniara High School, 10. Karail Govt. Primary School, 11. Dr. Ayesha Rajia Khondaker High School, 12. Agdhalla Govt. Primary School, 13. Baniara Babul Ulum Alia Madrasha, 14. Kadimdhalla Non-Govt. Primary School, 15. Baniara Govt. Primary School, 16. Katora Govt. Primary School, 17. Ufulky Govt. Primary School, 18. Chokoria Non-Govt. Primary School, 19. Gunutia Govt. Primary School and 20. Safdar Ali 
College of Jamurki on May to June, 2012. Water samples were collected from all school tube wells. So, the total numbers of water samples were collected from the schools were fifteen. $250 \mathrm{ml}$ of water were collected separately in plastic bottles. Before sampling, the bottles were cleaned and washed with sampling water. Necessary information such as date of collection, location, source of water, time of collection was recorded.

\section{Sample analysis}

Electrical conductivity (EC), $\mathrm{pH}$, total dissolved solid (TDS) and dissolved oxygen (DO) were measured by digital $\mathrm{pH}$, EC, TDS and DO meters respectively. The temperature of the water was determined by digital thermometer. $\mathrm{Fe}$ were determined with the help of Atomic Absorption Spectrophotometer (AAS, UNICAM, 969) at the Central laboratory of Bangladesh Agricultural
University, Mymensingh, followed the method of Clesceri et al. (1989). The wave-length of Fe 248.3 $\mathrm{nm}$. Aswas measured by the kit box in the laboratory of Environmental Science and Resource Management department of Mawlana Bhashani Science and Technology University. Data was processed and statistically analyzed by using SPSS statistical package (Evaluation version 14.0) and Microsoft Excel.

\section{Results and Discussion}

\section{Result and discussion on questionnaire survey}

The result found from data analysis of questionnaire survey by SPSS software and Microsoft Office Excel has been discussed below with graphical presentation. The following table contains the valuable information about the educational institutions.

Table 1. Result of questionnaire survey

\begin{tabular}{|c|c|c|c|c|c|c|}
\hline $\begin{array}{c}\text { Number of } \\
\text { institution }\end{array}$ & $\begin{array}{c}\text { Year of } \\
\text { establishment }\end{array}$ & $\begin{array}{c}\text { No. of } \\
\text { teacher }\end{array}$ & $\begin{array}{c}\text { No. of } \\
\text { student }\end{array}$ & $\begin{array}{c}\text { No of tube } \\
\text { well }\end{array}$ & No of toilet & $\begin{array}{c}\text { No. of } \\
\text { dustbin }\end{array}$ \\
\hline 01 & 1983 & 04 & 85 & 03 & 03 & 01 \\
\hline 02 & 1936 & 11 & 460 & 01 & 03 & 07 \\
\hline 03 & 1910 & 08 & 545 & 02 & 06 & 04 \\
\hline 04 & 1914 & 14 & 585 & 02 & 03 & 00 \\
\hline 05 & 1940 & 10 & 540 & 01 & 04 & 08 \\
\hline 06 & 2006 & 09 & 215 & 01 & 01 & 01 \\
\hline 07 & 1938 & 09 & 384 & 01 & 01 & 08 \\
\hline 08 & 2001 & 01 & 18 & 02 & 03 & 01 \\
\hline 09 & 1969 & 10 & 400 & 03 & 05 & 05 \\
\hline 10 & 1938 & 06 & 250 & 01 & 01 & 02 \\
\hline 11 & 2005 & 14 & 450 & 01 & 03 & 12 \\
\hline 12 & 1916 & 07 & 290 & 02 & 03 & 06 \\
\hline 13 & 1959 & 19 & 253 & 02 & 04 & 01 \\
\hline 14 & 1975 & 03 & 124 & 00 & 02 & 00 \\
\hline 15 & 1910 & 04 & 206 & 01 & 02 & 04 \\
\hline 16 & 1938 & 07 & 319 & 01 & 03 & 05 \\
\hline 17 & 1970 & 05 & 347 & 01 & 02 & 03 \\
\hline 18 & 1973 & 03 & 180 & 02 & 03 & 00 \\
\hline 19 & 1937 & 07 & 255 & 01 & 03 & 07 \\
\hline 20 & 2007 & 14 & 300 & 01 & 04 & 03 \\
\hline
\end{tabular}

Through the questionnaire survey we get more information about the sanitation practice. One of term of questionnaire survey was opinion about the drinking water quality. Most of the opinion was qualified about their drinking water. The result of drinking water quality has been shown in Table 2 .

Table 2. Respondent opinion about their drinking water quality

\begin{tabular}{|l|l|l|}
\hline $\begin{array}{l}\text { Less Qualified } \\
(\%)\end{array}$ & Qualified (\%) & $\begin{array}{l}\text { Very Qualified } \\
(\%)\end{array}$ \\
\hline 45 & 55 & 0 \\
\hline
\end{tabular}

From the figure we are watching 55\% respondent opinion was qualified and $45 \%$ respondent opinion was less qualified. But from the sample analysis we already know the water quality is good and all of samples are within standards. So we can say all of the tube well water is qualified for drinking purpose. In some institution the soap and toilet tissue present in toilet and in some institution these are absent. For sanitation practice the presence of soap and toilet tissue is must. Table 3 represents the presence of toilet tissue and soap in toilet of educational institution.

Table 3. Presence of soap and toilet tissue in toilet of educational institutions

\begin{tabular}{|c|c|}
\hline Present (\%) & Absent (\%) \\
\hline 40 & 60 \\
\hline
\end{tabular}

From the figure we easily understand in case of $40 \%$ the soap and toilet tissue is absent and in case of $60 \%$ these are present. Separate toilet facility for boys and girls is not available in all educational institution but in some institution this facility 
exists. In primary schools the separate toilet facility is not available but in high schools this facility is available.

Table 4. Percentage of separated or un-separated toilet facility

\begin{tabular}{|c|c|}
\hline Separate (\%) & Separate (\%) \\
\hline 50 & 50 \\
\hline
\end{tabular}

Table 4 shows the percentage of the facility of separate toilet.

\section{Water sample analysis}

The measured value of different physiochemical water quality parameters of collected samples has summarized in Table 5.

Table 5. Result of sample analysis of supplied water

\begin{tabular}{|c|c|c|c|c|c|c|}
\hline Sample no. & $\mathrm{pH}$ & $\mathrm{EC}\left(\mu \mathrm{S} \mathrm{cm}^{-1}\right)$ & $\mathrm{DO}\left(\mathrm{mg} \mathrm{l}^{-1}\right)$ & $\mathrm{TDS}\left(\mathrm{mg} \mathrm{l}^{-1}\right)$ & $\mathrm{As}(\mathrm{ppb})$ & $\mathrm{Fe}\left(\mathrm{mg} \mathrm{l}^{-1}\right)$ \\
\hline 01 & 6.7 & 392 & 2.5 & 370 & 0 & 0.6 \\
\hline 02 & 6.5 & 592 & 3.0 & 360 & 5 & 0.4 \\
\hline 03 & 6.6 & 367 & 3.8 & 442 & 0 & 0.7 \\
\hline 04 & 7.06 & 299 & 3.7 & 145 & 0 & 0.1 \\
\hline 05 & 7.8 & 495 & 3.2 & 390 & 5 & 0.7 \\
\hline 06 & 7.06 & 394 & 3.4 & 367 & 0 & 0.7 \\
\hline 07 & 6.8 & 392 & 3.1 & 445 & 0 & 0.8 \\
\hline 08 & 7.8 & 373 & 4.0 & 192 & 5 & 0.4 \\
\hline 09 & 7.5 & 462 & 3.2 & 240 & 15 & 0.5 \\
\hline 10 & 7.5 & 420 & 4.0 & 214 & 0 & 0.1 \\
\hline 11 & 8.2 & 386 & 2.5 & 202 & 5 & 0.1 \\
\hline 12 & 8.5 & 252 & 3.4 & 146 & 0 & 0.2 \\
\hline 13 & 7.3 & 414 & 3.8 & 211 & 5 & 0.1 \\
\hline 14 & 6.9 & 395 & 3.5 & 342 & 0 & 0.2 \\
\hline 15 & 7.6 & 354 & 3.5 & 184 & 5 & 0.6 \\
\hline 16 & 7.0 & 246 & 2.7 & 121 & 5 & 0.6 \\
\hline 17 & 7.8 & 437 & 3.5 & 225 & 0 & 0.9 \\
\hline 18 & 8.6 & 343 & 2.9 & 174 & 0 & 0.8 \\
\hline 19 & 8.3 & 442 & 3.0 & 228 & 5 & 0.4 \\
\hline 20 & 7.7 & 312 & 3.2 & 150 & 5 & 0.4 \\
\hline
\end{tabular}

Among the samples the maximum $\mathrm{pH}$ value 8.6 was found in one sample collected from Chokoria Non-Govt. Primary School (Sample no.18) and the minimum $\mathrm{pH}$ value 6.5 found in one sample collected from Jamurki Govt. Primary School (sample no. 02). In Bangladesh the standard value of $\mathrm{pH}$ for drinking water is 6.5-8.5. So the $\mathrm{pH}$ of tube well water of Ufulky Govt. Primary School has crossed the standard and other samples within the standard limit.

Electric conductivity (EC) values of all water samples were in Bangladesh drinking water standard value. In Bangladesh the maximum permissible value of Electric Conductivity (EC) is $1200 \mu \mathrm{S}$ (DoE, 1993).

The maximum concentration of TDS is $445 \mu \mathrm{S}$ in one sample collected from Pakulla Govt. primary school (Sample no. 07) and minimum if $121 \mu \mathrm{S}$ in one sample collected from Katora Govt. Primary School (Sample no 16). The Bangladesh standard for drinking water is $1000 \mu \mathrm{S}$ or $\mathrm{mg} \mathrm{l}^{-1}$.

The maximum amount of arsenic (As) is in the water of sample no.09 which was collected from Baniara High School. The minimum amount of As found in ten samples (Sample no. 01, 03, 04, 06, $07,10,12,14,17,18)$. The standard for As is 50 ppb.

The level of Fe concentration of all water samples is within the standard value of Bangladesh drinking water quality (According to DoE, 1993; Bangladesh drinking water quality standard of $\mathrm{Fe}$ is between $0.3-1 \mathrm{mg} \mathrm{l}^{-1}$ ). The maximum concentration of $\mathrm{Fe}$ is $0.9 \mathrm{mg} \mathrm{l}^{-1}$ among the samples collected from Ufulky Govt. Primary School and the minimum concentration of $\mathrm{Fe}$ is $0.1 \mathrm{mg} \mathrm{l}^{-1}$ found in four samples (Samples no.04, 10, 11, 14). The level of concentration of Iron of all water samples has given in Fig. 4.6 compared with Bangladesh drinking quality standard.

\section{Conclusions}

The water quality of the study area was relatively good except the $\mathrm{pH}$. All the values represent good quality water for drinking and using sanitation purpose. From survey it is obvious that the main causes of poor sanitation is the lacking of awareness, socio economic conditions and lacking of proper guidelines. 


\section{References}

Ahmed, M. F. and Rahman, M. M. 2000. Water Supply \& Sanitation, Rural and Low Income Urban Communities. (ITN-Bangladesh, Center for Water Supply and Waste Management, BUET, Dhaka, Bangladesh,).

DoE (Department of Environment). 1993. Environmental Quality Standard for Bangladesh, Ministry of Environment and Forestry, Government of Bangladesh.

Feroze, A. M. and Hasin, J. 2008. Participatory management of low-cost Water Supply and Sanitation.
WHO, 2000. Towards an Assesment of the Socioeconomic Impact of Arsenic Poisoning in Bangladesh. Geneva, World Health Organization

De, A. K. 2005. Environmental Chemistry. (Fifth Edition), New Age International (P) Ltd. Daryagang, New Delhi, India.

Clesceri, L. S.; Greenberg, A. E. and Trussel, R. R. 1989. Standard Method for the Examination of Water and Waste Water. $17^{\text {th }}$ edition, American Public Health Association, Washington D.C., 130, 40-175. 